\title{
Reflection on Personal ELL Experience and ELT Practice
}

\author{
Zhicheng Ma \\ Department of Foreign Languages, Chongqing Education College, Chongqing 400067, China \\ E-mail: dolphin7979@126.com
}

\begin{abstract}
Multitudes of language teaching practice shows that great attention drawn to language learning can help language teachers better their teaching and give appropriate learning support to language learners. A critical analysis of the author's English language learning experience is given in the paper, encompassing the approaches used, the role of the teachers, expectations on the learners at different times and the effectiveness of the learning. In addition, how the language teacher can benefit from this experience for his own TESOL (Teaching English to speakers of other languages) practice is addressed.
\end{abstract}

Keywords: Reflection, ELL experience, ELT practice

\section{Introduction}

It is commonly believed that teaching is for learning and learning is the goal of teaching. The function of teaching can be defined as a guide or catalyst in the process of learning, which reinforces effective learning and promotes learning achievement. On the other hand, the effect of learning reflects whether teaching approaches and methods are appropriate, providing feedback leading to adjustment or improvement of teaching methodology. Therefore, language teaching and learning interact closely with each other. As language teachers, we should attach importance to 'the learners themselves, the act of learning and the particular context in which this learning is to occur' (Nicholls, 2003:1). Great attention drawn to language learning can help language teachers better their teaching and give appropriate learning support to language learners. They can focus on or reflect on language learning in different ways. As Freeman (1992a) notes, 'Teachers' beliefs about learning may be based on their training, their teaching experience, or may go back to their own experience as language learners.'

Having been experiencing the whole process from being an English language learner to being an EFL teacher, I need to carry out some reflection on my ELL (English language learning) so as to be clear about what approaches should be adopted and what good practice should be implemented in my ELT (English language teaching). Based on the English language learning experiences I have undergone in Chinese schools, this paper emphasizes critical analysis of the approaches used, the role of my teachers, expectations on me and my fellow learners at different times and the effectiveness of my learning. It also discusses what I have learnt from this experience for my own TESOL (Teaching English to speakers of other languages) practice.

\section{Analysis of my English language learning experiences}

In China, the English language is regarded as a foreign language compared to the official language or mother tongue Chinese. The Cambridge Encyclopaedia of the English language defines EFL (English as a foreign language) as: English seen in the context of countries where it is not the mother tongue and has no special status (Crystal, 1995: 108). Long and Richards (1987) also mention: a non-native English speaker who studies English in an environment where the dominant population speaks a language other than English is studying EFL (Long \& Richards, 1987:4). Due to the role of English in China, Chinese English speakers mainly acquire the language at school as an academic subject. As Bright and McGregor (1977) have observed, 'If a language other than English is the medium of instruction in their school, then their only exposure to English will be in English lessons.' In the following, I will give an account of as well as analysis of my English language experiences at three different stages of my schooling.

\subsection{Junior high school phase}

I began to learn English at the age of 12, i.e. in 1984, when I studied in the first year of junior high school. It was a subject prescribed by the Chinese National Education Committee (CNEC) for junior high school students to learn with the intention of enriching students' knowledge and meeting students' professional requirement in the future. That is, English was not taught until junior high school in the Chinese educational system at that time. To unify teaching content and process, the CNEC issued the same English textbooks and set the same teaching curriculum and syllabus for all schools throughout the country. 
As junior high school introduces a primary level of English for Chinese students to learn, the textbook starts from very fundamental knowledge of the English language, including English phonetics, common words, simple sentence patterns and grammar. Learners are required to have a general command of English listening and speaking skills. In class, the English teacher asked the students to follow her to read the word or text, explaining the meaning of each word and giving examples of using the word. There were also a lot of sentence pattern drills but all was conducted by repeating mechanically what the teacher said. Though the expectation on training learners' listening and speaking skills should be addressed, few activities concerning such skills in the process of teaching were applied. The role of the teacher in such a class is only as a 'giver' of information in that no effective interaction occurs between the teacher and the learner. The approach that is used in this type of English teaching can be thought of as a teacher-centred or cramming approach for the teacher dominates the process of language teaching and learning from beginning to end.

This period of English language learning brought me a little interest in learning English. It was not because I could just pass the English examination without obtaining a high mark, but because I did not obtain the required skills of learning the language. I could not understand what the native speakers said on the tape. Nor did I use English to communicate with others. Reflecting on this experience, I have found out the teacher-centred approach may not be a good way to suit students' language acquisition, though it helps to build up the basic system of the English language, especially grammar. In the process of such learning, the fact that learners may have very different goals is not valued. For example, acquiring a native-like accent in English might be considered an important goal for me in that I could speak English fluently with native-speakers if I could study in an English-speaking country. Students in such a class, nevertheless, could not get any opportunity to talk or use elementary English to express what they want to say. The approach stresses the role of the teacher in imparting the knowledge to the learner only through himself or herself, paying little attention to the role of the teacher as a helper or guide, and the role of the learner. On the teacher's role in language teaching, Brindley (1984: 9) notes:

It is the role of the teacher to assist learners to become self-directed by providing access to language data through such activities as active listening, role play and interaction with native speakers.

\subsection{Senior high school phase}

My English language learning in senior high school gradually helped me to develop a systematic English grammar. During this stage, English language teaching focused on cultivating students' general reading and writing skills in the language. Another goal of teaching at this level was to integrate and refine what students had been taught in the subject of English so as to prepare them for the CEC (College entrance examination). In classroom teaching and learning, we got a lot of illustrations of grammatical rules and analysis of sentence structures from the English teacher. We also gave responses to the content-oriented questions raised by the teacher, giving examples for a grammatical point or key sentence pattern. To ensure we had a better comprehension of the text, the teacher often translated most sentences into Chinese. Once a week, we submitted an English diary in order to practise writing.

The approach used in this stage can be viewed as the grammar-based teaching and translation method. The former indicates that grammar has a central role in language teaching. In this approach, the teacher plays a dominant role in illustrating English grammar step by step so that students can understand how English sentences are grammatically structured and how they can employ English correctly either in speech or written form. This traditional grammar-based instruction has been widely criticized as being ineffective, yet grammar can influence the four skills of learning a foreign language. For example, if an EFL learner does not have a grasp of fundamental English grammar, he or she may have difficulty in uttering or writing an English sentence which is accepted or understood by native speakers. Similarly, the learner cannot comprehend what English reading material is about and what native speakers are talking about on tape or in real life if he or she has little knowledge of English grammatical rules. Accordingly, it is entirely essential for the foreign learner to grasp English grammar. As Bright and McGregor (1977:236) point out:

Nobody disputes that the foreign student must learn the grammar of English in the sense that the sentences he produces must conform to English patterns in the accepted mode.

With systematic grammar knowledge, students can easily distinguish grammatical phenomena they encounter and do well in their CEE. However, the communicative ability of students like speaking and listening is not developed in this process of language teaching and learning.

The translation method emphasizes studying another language by translating it into L1 (first language). In this approach, the first language is used as a medium of understanding the foreign language and the teacher guides the student from the target language to the mother tongue, which makes the student clear about the differences between the two languages. Nicholls $(2003,78)$ also says that the traditional Translation approach 'has a cognitive orientation, regarding the language as an object to be studied rather than as a tool to be used, and thus encouraging students to study its grammatical and other systems, particularly in their written form, comparing them with those of the mother-tongue' As a result of interference from $\mathrm{L} 1$, the language environment of the target language cannot be fully exposed to the learner, 
and the learner does not actually get enough practice of the target language. Affected by this sort of teaching method, some of my fellow learners rarely used English without thinking of Chinese first.

\subsection{Tertiary education phase}

It was in the University that I acquired basically the four skills of using English: listening, speaking, reading and writing. During college, we followed different courses relating to the training of each skill and were expected to study the English language at greater depth through guidance from the language activity or self-exploration. In class, the teacher gave lectures on a variety of topics associated with the English language, assisting us to obtain academic and professional skills in the field of English language learning and future teaching.

The approach adopted in this stage can be called Active Teaching that focuses on the teacher's ability to involve students productively in learning tasks during lessons (Richards \& Lockhart, 1994:102). In this methodology, the teacher sets a task to engage the students or raises a topic for them to discuss, providing chances for learners to practise the language actively and creatively. In the process of involvement, besides language competence, other abilities like logical thinking and reasoning can also be achieved. Furthermore, language learners can continue to develop their interlanguage, a system of abstract linguistic rules which underlies comprehension and production of the L2 (Ellis, 2002:33).

\section{My TESOL practice}

Reflection on the English language learning experiences I have undergone lets me gain useful insights on what to teach and how to teach in my English language teaching. It is vital to consider what methodologies in TESOL fit our social context and the special teaching targets which I am facing, and how to design my teaching and implement good practices of language teaching with the purpose of helping my students gain effective strategies for learning the language.

The methodology employed in my own TESOL practice, is mainly based on the three terms: approach, design, and procedure, which are 'used to label three interrelated elements of organization upon which language teaching practices are founded' (Long \& Richards, 1987:146). 'Approach' refers to the language teaching method that language teachers adopt in their teaching. All language teaching methods operate as guidance and provide theoretical foundations for what language teachers may do with learners in classroom. The method I have applied in my teaching generally relies on my students' learning level and teaching contents. 'Design' specifies how language teachers plan the instruction with a particular approach. The design for my language teaching relies on specifications of the content, my roles, the students' roles and teaching aids. 'Procedure' focuses on the actual teaching techniques, practices and activities that operate in the process of English language teaching and learning. Usually, at this level, I provide the students with communicative language tasks and activities. According to the three elements of language teaching practice, most of my teaching practice shows that I prefer using the two methodologies or approaches: learner-centred and cooperative learning.

\subsection{Learner-centred approach}

In this approach, the teacher's role changes from a language instructor to a language guide, organizer or facilitator, while the learner has a central and active role in the process of language learning. I often supply students with different sorts of activities which involve their participation in learning by doing and practising English. One of these activities I would like to mention here is brainstorming. I design such questions in accordance with what I am going to teach and what the students are supposed to learn and grasp, usually without a fixed answer, to challenge the students' thinking or create more opportunities in class for them to ask meaningful questions. For instance, in one of my listening and speaking classes for college students, I asked the student a question challenging their brains after we had listened to the material and discussed the listening comprehension questions in the textbook, to which we could get the answers directly from the listening material. The main content of the material is about Mr. Brown was taking the 4 PM train to London. It was 4:25 PM, but the train did not depart. Mr. Brown felt very angry, and he was out of temper with one of the train staff. Finally, he was told that he had got on the wrong train. My question is 'Why did Mr. Brown take the 4 PM train to London?' The students could not find out the answer from the material, yet the question drew their attention to give a possible answer with their imagination and they actively worked out lots of the answers, such as Mr. Brown wanted to visit his friends; He lived in London; He was an artist and went there to see a painting exhibition, etc. By working at the answers, the students can practise the language they have learned and develop their thinking ability.

I also organize pair-work and group discussion in terms of the task or topic, arousing their interest in learning the language. Take one pair-work activity I designed as an example. Two students were required to think out three or four questions concerning job-hunting, took turns to ask their partner and noted down the answers. To let them have a group discussion, I even set a task in which the students in a group of five talked about one effective way of dealing with water pollution in the city. After a 10-minute discussion, a reporter from each group gave a presentation before the class about what they had discussed and how they would carry out the plan. The students' achievements in these activities prove that the learner-centred approach in ELT can be very practicable and also important for language teachers to take 
some practice. As Armstrong (1992:114) quoting Omaggio-Hadley (1986) has pointed out, students frequently become more motivated after being given individual opportunities to share information about themselves and their interests with their teacher.

\subsection{Cooperative learning}

This methodology 'relies less on teacher-directed teaching and more on cooperative group work and pair work activities' (Richards \& Lockhart, 1994:102). Before the students are thrown into the situation of cooperative learning, one thing I have to focus on is to let them know what they are going to do and why they need to do that. Most importantly, I always make sure the tasks planned can engage students in achieving learning goals or solving problems through collaborative reasoning, opinion sharing or values clarification. One cooperative learning activity I carried out with my students is the students worked collaboratively in groups of four, talking in English about the characteristics of a good friend, choosing the two most important they all agreed on and giving the reasons. By working with their group members, the students put what they had learned into topic-oriented and real use, shared opinions with each other and made joint efforts to fulfil the learning task. As proposed by Colville-Hall (1992:55), 'Cooperative learning is vital because it can provide the opportunity for students to develop skills in cooperation and in communicative competence.'

\section{Conclusion}

In sum, language teachers would profit from reflecting on their own experience as language learners, from the role of their former language teachers, which provides them with a good reference point and guidance in their ELT and makes teaching become an aid to the learners in the process of language learning, not a hindrance to the fulfilment of the students' individual interests and the realization of their potentials.

\section{References}

Armstrong, Gregory K. (1992). 'Learner-Initiated and Learner-Friendly: Questions to Get Them Talking' in Creative Approaches in Foreign Language Teaching, National Textbook Company, Lincolnwood (Chicago).

Bright, J. A. \& McGregor, G. P. (1977). Teaching English as a Second Language, Longman, London.

Brindley, G. P. (1984). Needs Analysis and Objective Setting in the Adult Migrant Education Program. AMES, Sydney.

Colville-Hall, Susan. (1992). 'A Case for Cooperative Learning in the Foreign Language Classroom' in Creative Approaches in Foreign Language Teaching, National Textbook Company, Lincolnwood (Chicago).

Crystal, David. (1995). The Cambridge Encyclopaedia of the English Language, Cambridge University Press, Cambridge.

Ellis, Rod. (2002). Second Language Acquisition, Oxford University Press, Oxford.

Freeman, D. (1992). Language teacher education, emerging discourse, and change in classroom practice. In J. Flowerdew, M. Brock, and S. Hsia (eds.), Perspectives on Second Language Teacher Development, City Polytechnic of Hong Kong, Hong Kong Pp.1-21.

Long, Michael H. \& Richards, Jack C. (1987). Methodology in TESOL, A Book of Readings, Newbury House Publishers, New York.

Nicholls, R. (2003). Lecture Notes, TESOL Methodology Module1, the University of New England, Armidale.

Richards, Jack C., \& Lockhart, Charles. (1994). Reflective Teaching in Second Language Classrooms, Cambridge University Press, Cambridge. 